\title{
Geographic and ecological analysis of the Bearded Wood Partridge Dendrortyx barbatus: some insights on its conservation status
}

\author{
CLAUDIO MOTA-VARGAS, OCTAVIO R. ROJAS-SOTO, \\ CARLOS LARA, CITLALLI CASTILLO-GUEVARA and \\ CLAUDIA BALLESTEROS-BARRERA
}

\section{Summary}

Delimiting the distribution of a species is a complex task because many determining factors are difficult to assess in the field. This is important because distribution is a key factor in the decisionmaking process for conservation. One example is the Bearded Wood Partridge Dendrortyx barbatus, a species endemic to the temperate forests of the Sierra Madre Oriental (SMO) mountain range in Mexico. Lack of knowledge of its distribution has generated confusion over the assignment of the correct risk category. With the aim of predicting the distribution area of the Bearded Wood Partridge and contributing to strategies for its conservation, we updated and extended the knowledge of its distribution by modelling its ecological niche using GARP and MaxEnt algorithms. We also analysed its environmental distribution using principal components analysis, and contrasted the two most important environmental variables with the species's distribution based on vegetation type. We found that the area potentially occupied by this species covers $17,956 \mathrm{~km}^{2}$ according to GARP and $12,974 \mathrm{~km}^{2}$ according to MaxEnt. We suggest that there is a biogeographic barrier which limits the distribution of this species in the southern part of its range. The abiotic variables that best explain its distribution are average annual precipitation and elevation, both of which coincide well with the distribution of cloud forest. A redefinition of the current range as recognised by IUCN is proposed along with the need to change its national risk category.

\section{Resumen}

Delimitar el área de distribución de una especie es una tarea compleja debido a que los factores que la determinan son difíciles de evaluar en campo; sin embargo, esto es importante porque el área de distribución de una especie es un factor determinante para la toma de decisiones en conservación. Este es el caso del Chivizcoyo Dendrortyx barbatus, una especie endémica a los bosques templados de la Sierra Madre Oriental (SMO) en México, cuya falta de conocimiento de su área de distribución ha generado confusión con respecto a su categoría de riesgo. Con el objetivo de predecir el área de distribución y contribuir con estrategias para su conservación, hemos actualizado y ampliado el conocimiento en torno a su distribución mediante el uso de modelado de nicho ecológico utilizando los algoritmos GARP y MaxEnt. También analizamos la distribución ambiental mediante un análisis de componentes principales y contrastamos las dos variables más importantes con los tipos de vegetación que frecuenta la especie. Los resultados obtenidos fueron que el área de distribución potencial de la especie de acuerdo con GARP fue de $17,956 \mathrm{~km}^{2}$ y $12,974 \mathrm{~km}^{2}$ con base en MaxEnt. Sugerimos la existencia de una barrera biogeográfica que delimita su área al sur de su distribución. La precipitación media anual y la altitud son las dos variables que explicaron mejor los patrones de distribución de la especie, cuyos valores coincidieron mayormente con el bosque mesófilo de 
montaña. Proponemos una redefinición del área de distribución de la especie reconocida por la IUCN y consideramos que es necesaria una modificación en su categoría de riesgo a nivel nacional.

\section{Introduction}

Delimiting the distribution of a species is a complex task as many determining factors (abiotic and biotic conditions, dispersal capability and adaptability to new conditions, among others) are difficult to assess in the field (Soberón and Peterson 2005). In addition, there are marked differences between the methods available for determining such boundaries (e.g. Mota-Vargas and Rojas-Soto 2012). However, it is very important to delimit the distribution of a species as accurately as possible, as this has fundamental implications for the systematics, biogeography and particularly the conservation of the species (Mota-Vargas and Rojas-Soto 2012). Such is the case of the Bearded Wood Partridge Dendrortyx barbatus, a species endemic to the temperate forests of the Sierra Madre Oriental (SMO) mountain range in Mexico. Although the species is currently listed as "Vulnerable" (IUCN 2000), the understanding of this species's distribution has changed frequently and this has had important implications for assessing its risk category (Collar et al. 1992, Howell and Webb 1995, IUCN 2000, Eitniear et al. 2008).

Since its description by Gould in 1844, the limited cumulative knowledge of the natural history and distribution of the Bearded Wood Partridge has led to its classification as ecologically and geographically rare (Collar et al. 1992) and it was therefore assessed as "Critically Endangered" in 1994 (IUCN 2008, SEMARNAT 2011). However, when new records of the species provided more information about its environmental requirements, it was suggested that its known range be expanded (Eitniear et al. 2000, Aguilar 200o). Its global threat category was changed to "Vulnerable", two levels of risk lower than before (IUCN 2008), although SEMARNAT (2011) in its latest version of the Official Mexican Legislation (the NOM-ECOL-059), continued to list it as "Endangered".

In addition to the distribution size, other criteria are necessary to assign categories of risk; for example, population size and threats to a species such as the transformation of disturbed natural environments (Aldama et al. 2007). In the case of the Bearded Wood Partridge, not many aspects of its biology are known, mainly because it is difficult to observe in the field, which has hindered research. For example, little is known about the habitat requirements of this species. It was originally regarded as almost exclusively associated with cloud forest. However, there have been recent records of the species in pine-oak forests, pine forests, tropical medium forest and even shaded coffee crops (Eitniear et al. 2001, Aguilar 2003). These records indicate that its ecological requirements are less specific than previously thought.

Traditionally the analysis of species' distributions has used locality records to delimit their range; however, in most cases, there are few records and even when there are a sufficient number of them, they are biased by site accessibility (Peterson et al. 1998). Recently an increasing number of algorithms based on ecological niche modelling (ENM; Elith et al. 2006) are being used to improve our knowledge of species distribution by filling in gaps in geographic data (Godown and Peterson 2000, Anderson et al. 2002, Rojas-Soto et al. 2003, Mota-Vargas and Rojas-Soto 2012). ENM require the use of the locality records available for a species in combination with environmental data (Pulliam and Dunning 1997, Carroll et al. 1999, Manel et al. 1999, Cowley et al. 2000).

The present study was carried out with the aims of compiling updated records of Bearded Wood Partridge in the field, modelling its ecological niche, and analysing its ecological and geographical distribution to refine our understanding of its current area of distribution.

\section{Methods}

\section{Collection of historical records}

We compiled a database of all available records from two sources: available digital information, including the Global Biodiversity Information Facility database (GBIF, www.gbif.org; 83 records), 
the World Information Network on Biodiversity (REMIB 2010; 22 records), and the Atlas of the Birds of Mexico (Navarro-Sigüenza et al. 2003; 47 records). Records from literature were also used (Lowery and Newman 1951, Davis 1952, Collar et al. 1992, Eitniear et al. 2000, 2001, Rojas-Soto et al. 2001, Aguilar 2000, 2003, Martínez-Morales 2007, Villa-Bonilla et al. 2008, Mota-Vargas 2008; 47 records). Records repeated in multiple sources were removed and only information from the original source was used. We omitted all doubtful and ambiguous information (i.e. information that did not have precise data locality and records with dubious coordinates that could not be verified). We georeferenced each locality with the help of gazetteers (INEGI 1992) and in some cases with the use of Google Earth (http://earth.google.es/). After removing duplicate information and verifying the coordinates, we had a total of $4 \mathrm{I}$ historical records, which were used to run the first ENM using the GARP algorithm (Figure 1 ; details below) which formed the basis for the selection of certain regions and also for conducting intensive field work to search for and verify historical localities (Mota-Vargas and Rojas-Soto 2012).

\section{Field work}

Based on the first ENM (Figure 1 ) we selected 22 regions from a large part of the potential distribution area of the species (also identifying some of the historically associated localities) to

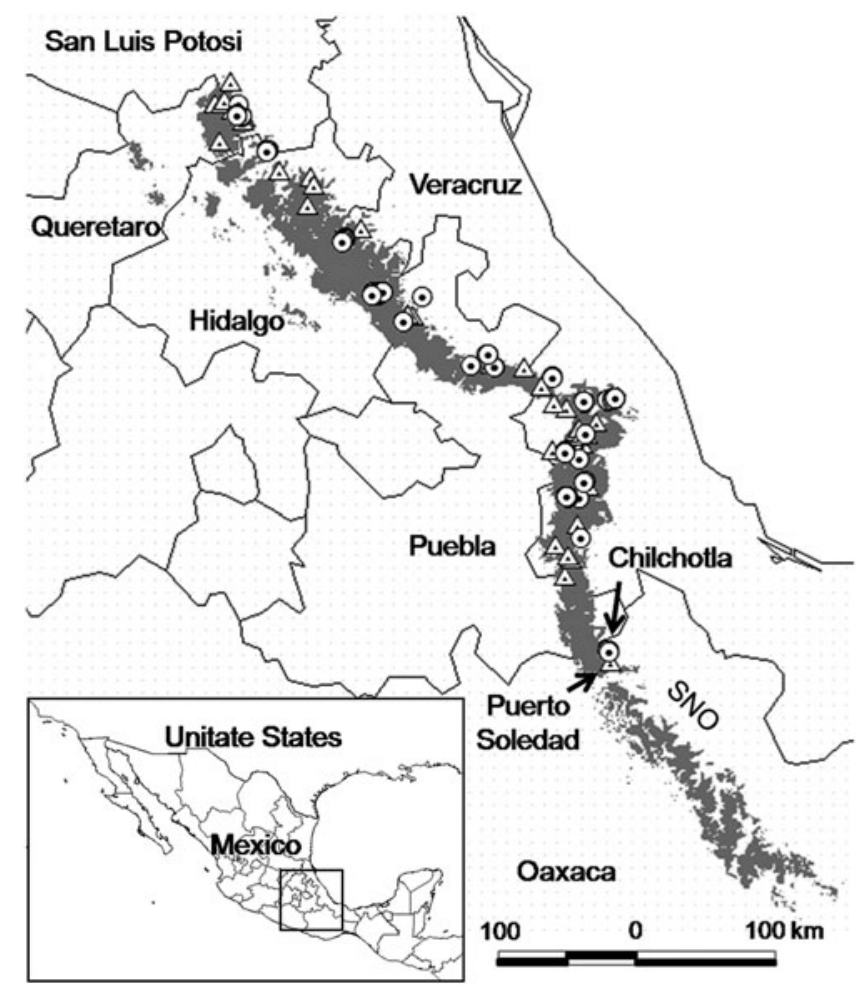

Figure 1. Geographical distribution of the Bearded Wood Partridge obtained using GARP (dark grey) from 41 historical records $\left(\sim 21,971 \mathrm{~km}^{2}\right.$, including the Sierra Norte de Oaxaca). The triangles correspond to historical records, the white dots correspond to field work records. The two southernmost known localities where the species was recorded are shown with arrows (Puerto Soledad and Chilchotla). The thin black lines are the state lines. 
carry out field surveys and to obtain new localities for the species. The field work was carried out over a period of eight months (April-November 2010) with a total of 20 days in the field. Due to the cryptic nature of the species and the difficulties in observing these birds directly, we applied the playback technique proposed by Carroll and Hoogesteijn (1995). This consists of transmitting the song of the species for 30 seconds, waiting for 30 seconds to listen for a response and playing the song again; this is done three times in a row, for a total time of three minutes. It has been widely demonstrated that the species responds to such auditory stimuli (Aguilar 2000, Eitniear et al. 2001). Digital recordings of the Bearded Wood Partridge (territorial song of a male) were used, as recorded in 1996 by Eitniear in Coatepec, Veracruz, and played on a CD player connected to an amplifier.

Sampling was carried out between $06 \mathrm{~h}_{30}$ and 10 hoo, and again from $18 \mathrm{~h}_{30}$ to $20 \mathrm{hoo}$, because these are times of highly vocal activity (Eitniear et al. 2001, Aguilar 2003). At each sampling point, a high, clear location was chosen to provide an observation point and a good auditory environment, although in some cases playback was carried out inside the forest. The amplifier was aimed in different directions to obtain a response from the species, data were collected on the presence or absence of the species, and the geographical coordinates were obtained using a Garmin XL12 GPS device. Occasionally, upon arrival at the sampling site, the bird sang spontaneously (i.e. without the auditory stimulus). The bird's presence at such sites was corroborated immediately using the playback method and the corresponding data were recorded. If a response was obtained the first time the bird's song was played, the information was recorded and then another locality was visited. When the species did not respond at the first monitoring point, a new point was sought (approximately $100 \mathrm{~m}$ away), and so forth until we got a response or until we had attempted to get a response at five different points. The geographic coordinates of the location where each response was obtained were noted (compass direction and estimated distance) and points were plotted on a digital map of the study area with the assistance of the Arc View 3.2 Geographic Information System (GIS) (ESRI 1999) and Google Earth (2010). Based on the new locality records obtained during the field surveys ( 95 records) we ran a second ENM (41 historical records +95 field surveys records $=136$ records) using two algorithms (see below for details).

Since we did not record the species as present at any of the sites we first visited in the southern region, we increased the number of sites to search along two geographic routes. The first route was approximately $25 \mathrm{~km}$ long and characterised mainly by pine and cloud forest. The second route covered $20 \mathrm{~km}$ and was characterised mainly by pristine cloud forest. In both cases, a comprehensive search was conducted in localities along these two routes and that were an average of $2 \mathrm{~km}$ away from one another. These efforts were fruitless, in spite of adequate weather conditions and only a day's difference from monitoring the other locations where the species was recorded frequently.

\section{Ecological niche modelling}

In both ENM exercises, we used 22 environmental variables to characterise the species's niche: 19 bioclimatic variables obtained from the WorldClim project (Hijmans et al. 2005) and three topographic variables from the Hydro IK project (USGS 2001), both with a spatial resolution of $0.0083^{\circ}\left(\sim 1 \mathrm{~km}^{2}\right.$; Table 1$)$.

We used the Genetic Algorithm for Rule-set Production (GARP). In order to compare the results obtained during the second ENM, we used MaxEnt, another widely used algorithm. The application of GARP has been well documented in extrapolation exercises (Peterson, 2003a, b, Raxworthy et al. 2003, Peterson et al. 2005), although some authors have suggested that MaxEnt has better predictive success rates, particularly for small sample sizes (Pearson et al. 2006, Elith et al. 2006). The differences between these widely used algorithms are not a concern since they do not differ significantly (Tsoar et al. 2007; Warren et al. 2008). Furthermore, both algorithms have been used widely in the delimitation of bird distributions (e.g. Godown and Peterson 2000, Peterson 2001, Phillips et al. 2004, Rojas-Soto et al. 2008). 
Table 1. Environmental variables used for ecological niche modeling.

\begin{tabular}{|c|c|}
\hline 1 & ВIO $1=$ Annual average temperature \\
\hline 2 & $\mathrm{BIO}_{2}=$ Average daily range (mean monthly $(\max$ temp - min temp)) \\
\hline 3 & $\mathrm{BIO}_{3}=$ Isothermality $\left(\mathrm{P}_{2} / \mathrm{P}_{7}\right)\left({ }^{*}{ }_{100}\right)$ \\
\hline 4 & $\mathrm{BIO}_{4}=$ Temperature seasonality (standard deviation $\left.{ }^{*} 100\right)$ \\
\hline 5 & $\mathrm{BIO}_{5}=$ Maximum temperature of warmest month \\
\hline 6 & BIO6 = Minimum temperature of coldest month \\
\hline 7 & $\mathrm{BIO}_{7}=$ Annual temperature range $\left(\mathrm{P}_{5}-\mathrm{P} 6\right)$ \\
\hline 8 & $\mathrm{BIO} 8=$ Average temperature of wettest quarter \\
\hline 9 & $\mathrm{BIO}_{9}=$ Average temperature of driest quarter \\
\hline 10 & $\mathrm{BIO}_{10}=$ Average temperature of warmest quarter \\
\hline 11 & $\mathrm{BIO}_{11}=$ Average temperature of coldest quarter \\
\hline 12 & $\mathrm{BIO}_{12}=$ Annual precipitation \\
\hline 13 & Bio1 $3_{3}=$ Precipitation in wettest month \\
\hline 14 & Bio14 $=$ Precipitation in driest month \\
\hline 15 & Bio15 $=$ Seasonality of precipitation (coefficient of variation) \\
\hline 16 & BIOı6 = Precipitation in wettest quarter \\
\hline 17 & $\mathrm{BIO}_{17}=$ Precipitation in driest quarter \\
\hline 18 & $\mathrm{BIO}_{1} 8=$ Precipitation in warmest quarter \\
\hline 19 & $\mathrm{BIO}_{19}=$ Precipitation in coldest quarter \\
\hline 20 & $\begin{array}{l}\mathrm{CTI}=\text { Topographic index (a function of upstream contributing area and slope } \\
\text { that reflects tendency to pool water) }\end{array}$ \\
\hline 21 & SLOPE = Slope \\
\hline 22 & Elevation $=$ Metres above sea level \\
\hline
\end{tabular}

GARP is an artificial intelligence algorithm that uses points of presence in combination with digital environmental data, and works in an iterative way based on rules (atomic, logistic regression and ranges; see Stockwell and Peters 1999). The resulting model is a product of the relationship between localities and environmental variables. These rules are evaluated and tested and then they are incorporated into or rejected by the model based on their behaviour. This process continues successively until a set of rules are produced that describe the ecological niche which can later be projected into geographic space, producing a prediction of potential presence (Stockwell and Noble 1991, Stockwell and Peters 1999). We ran 100 models for Bearded Wood Partridge; for each model we used $80 \%$ of the locality records and the other $20 \%$ were used for evaluation. The interface of the program allowed the best subset to be obtained, so we chose the 10 best models with a default value of $10 \%$ or less of the omission error; we then selected the models whose values were closest to the median of the commission error value (Anderson et al. 2003). The final consensus map included $98 \%$ of the records.

MaxEnt (Phillips et al. 2006) uses the principle of maximum entropy to calculate the most likely distribution for each species. Eighty percent of the localities were used as training points and $20 \%$ were validation points; the maximum number of iterations was 1,000 with a convergence limit of 0.00001 and a regularisation value of 1 . The prediction obtained (in terms of probability between $O$ and $I$ ) was transformed to a binary map (where $O$ is absence and $I$ is presence) with a threshold value of 0.229 that included $98 \%$ of the records. The final maps (from GARP and MaxEnt) were edited to remove the areas predicted but that are far from the known range of the species. The maps were edited using GIS.

\section{Analysis of the ecological distribution patterns}

The ecological distribution was first analysed with a description of the value ranges for each of the 22 variables for each locality where the species was recorded. With these values, we conducted 
a principal component analysis (PCA) using the program PAST (http://norges.uio.no/past/ download.html) to analyse the most important environmental variables. We graphically compared the interaction between the values of the two most important variables for the first principal component. These values were obtained and compared for: a) each of the locality records, $b$ ) each of the pixels of potential presence (GARP only) combined with the primary vegetation of Mexico, which corresponds to "vegetation that would develop in an area under environmental conditions similar to today, without human influence" (INEGI 2003), and c) for the pixels representing the $\mathrm{SMO}$; this with the aim of viewing the environmental requirements of the species in a geographic context.

\section{Results}

The first modelling exercise predicted an area of $21,971 \mathrm{~km}^{2}$ and includes $40(98 \%)$ of the historical records (Fig. 1). From the 22 regions visited during the field work, we obtained 95 new locality records, of which $77(81 \%)$ were in areas predicted by the first model, and the other 18 (19\%) were in non-predicted sites (Appendix 1). In addition, based on the map, an intensive search was also conducted along two routes in the Sierra Norte of Oaxaca (SNO), but the species was not detected there.

The two final versions of the potential geographic distribution maps (Figure 2) generated by GARP and MaxEnt, delimit the species's distribution using 136 records (41 historical +95 from

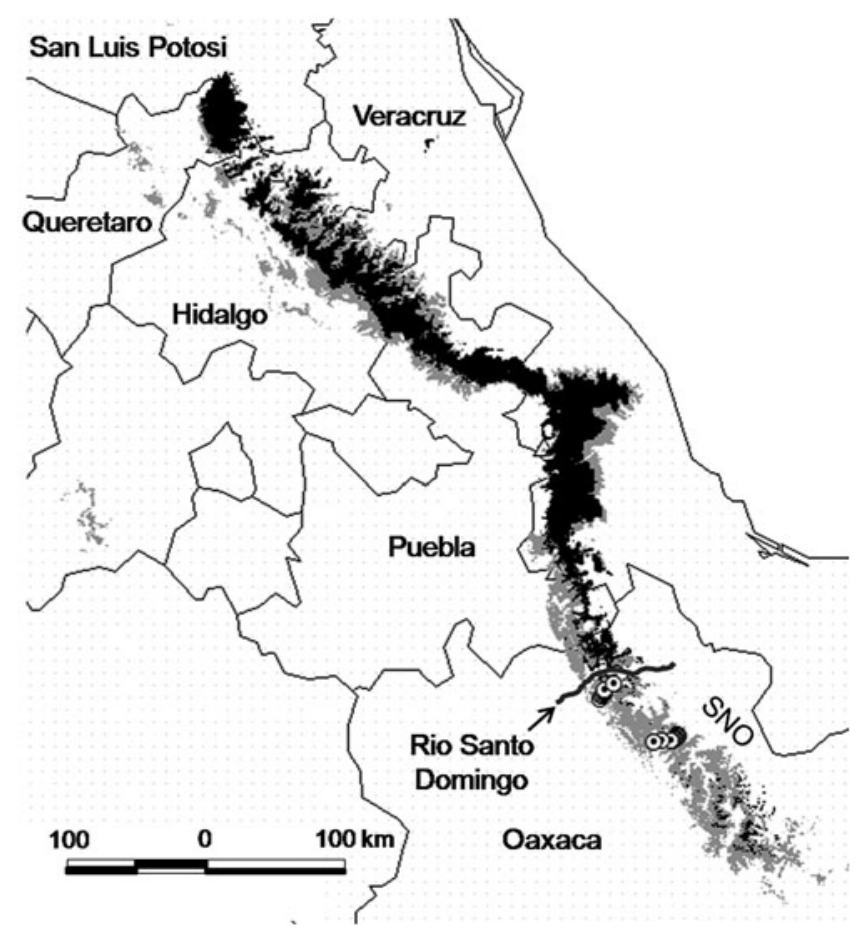

Figure 2. Geographical distribution of the Bearded Wood Partridge derived from the final exercise of ecological niche modeling. The geographical distribution obtained using MaxEnt is in black, the geographical distribution obtained using GARP is in dark grey. The white dots indicate the sites where the species was not detected. The arrow and wide grey line highlight the location of the Santo Domingo River. The thin black lines are the state lines. 
field work). Both maps have the same distribution patterns, are based on good prediction accuracies (for GARP $\chi^{2} 333-369 \mathrm{P}<0.05$ and for MaxEnt AUC $=9.73$ ), overlap by $11,914 \mathrm{~km}^{2}$ (i.e. $92 \%$ overlap of GARP in relation to MaxEnt), and in both cases include the potential presence of its ecological niche in the SNO. However, based on historical surveys and the field work carried out in this study, Bearded Wood Partridge appears to be absent south of the Santo Domingo River, suggesting that the river could represent a climatic barrier limiting the geographical distribution of the species and reducing its distribution to an area of approximately $17,956 \mathrm{~km}^{2}$ according to GARP, and $12,974 \mathrm{~km}^{2}$ according to MaxEnt.

With respect to the 22 environmental variables (Figure 3 and Table 1 ), Bearded Wood Partridge occurs in temperature and precipitation ranges that do, in fact, correspond to temperate forests; however, the narrow range of isothermality is noteworthy as is the relatively wide range of seasonality.

From the results of the PCA (Figure 4, Table 2), the first principal component explained close to half of the variance $(42 \%)$ and the two variables with the most weight were annual precipitation and elevation; for component two $(31 \%)$ the most important variables were slope and seasonal temperature. Figure 3 shows the values for principal components 1 and 2, and highlights the localities across four altitudinal intervals for the purpose of demonstration. Component one describes a clear altitudinal pattern, segregating highland (over 2,000 $\mathrm{m}$ a.s.l.) from lowland $(1,200 \mathrm{~m})$ records, and showing that most of the records occur between 1,200 and 2,000 $\mathrm{m}$.

From the comparison of average annual rainfall and elevation among the locality records, the pixels that represent the potential geographical distribution (ENM) and the pixels that correspond to the SMO (Figure 5), it is apparent that there are environmental restrictions on the values of the localities and potential presence with respect to the values of the SMO. Based on comparison of the different types of vegetation that make up the potential distribution obtained, cloud forest coincided with the species's main ranges of elevation and precipitation, while the elevation range of the medium-sized deciduous forest was more restrictive for Bearded Wood Partridge. The elevation range of pine-oak forests was favourable although the range of precipitation they receive partially restricts the distribution of this species. Based on the geographical location of the 136 records of this
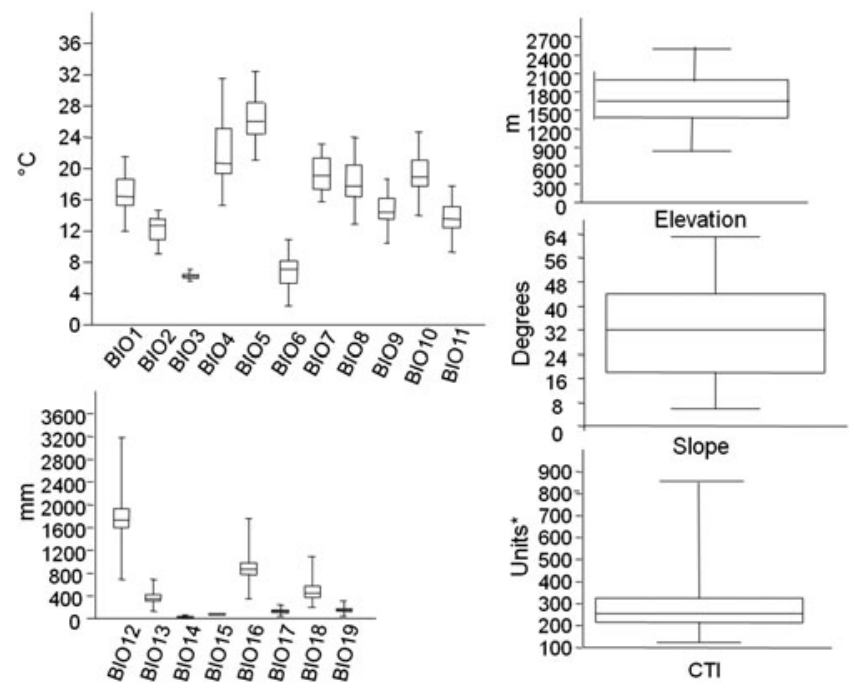

Figure 3. Climatic description of the species based on its potential presence. Displayed is the interval of values for each of the variables used for modeling as follows: Bior-Bio11 are temperature and Bio12-Bio19 are precipitation values. ${ }^{*} \mathrm{CTI}$ units are explained in HYDRO $1 \mathrm{~K}$ (http://edc.usgs.gov). 


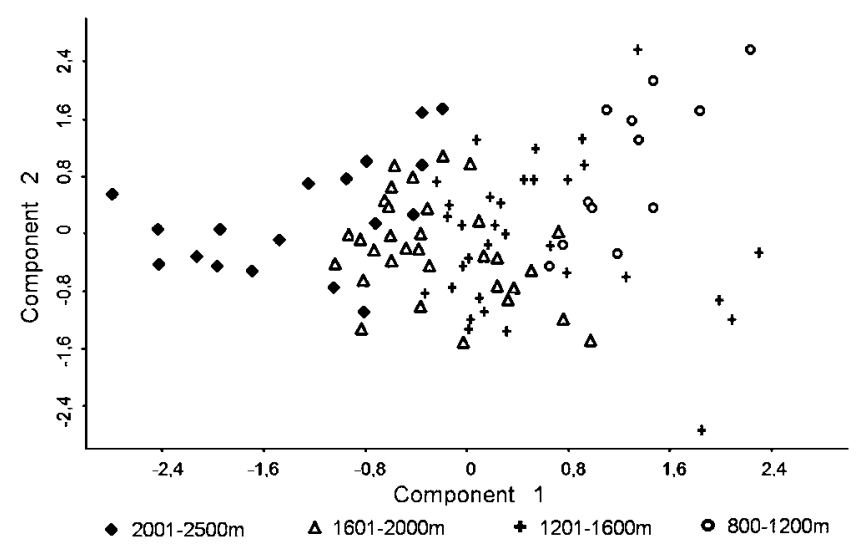

Figure 4. Analysis of the first two principal components. Symbols indicate the locality records according at four elevation intervals.

species, 89 localities were situated in cloud forest, 37 in pine-oak forest and to in medium deciduous forest.

\section{Discussion}

Due to disagreement about the geographical and ecological distribution of the Bearded Wood Partridge, it was first necessary to carefully compile the historical and currently known locality

Table 2. Coefficients for each of the variables of the first three principal components. Numbers in bold indicate the most important variables.

\begin{tabular}{|c|c|c|c|}
\hline Variable & $\mathrm{PC}_{1}$ & $\mathrm{PC}_{2}$ & $\mathrm{PC}_{3}$ \\
\hline $\mathrm{BIO}_{1}$ & 0,0291 & 0,0014 & $-0,0198$ \\
\hline $\mathrm{BIO}_{2}$ & 0,0007 & 0,0126 & 0,0072 \\
\hline $\mathrm{BIO}_{3}$ & $-0,0021$ & $-0,0020$ & 0,0038 \\
\hline $\mathrm{BIO}_{4}$ & 0,3356 & 0,5267 & $-0,3801$ \\
\hline $\mathrm{BIO}_{5}$ & 0,0322 & 0,0137 & $-0,0183$ \\
\hline BIO6 & 0,0238 & $-0,0126$ & $-0,0183$ \\
\hline $\mathrm{BIO}_{7}$ & o,oo84 & 0,0263 & 0,0000 \\
\hline BIO8 & 0,0336 & 0,0065 & $-0,0253$ \\
\hline $\mathrm{BIO}_{9}$ & 0,0255 & $-0,0056$ & $-0,0126$ \\
\hline BIOıо & 0,0318 & 0,0062 & $-0,0222$ \\
\hline BIOII $_{11}$ & 0,0243 & $-0,0061$ & $-0,0140$ \\
\hline $\mathrm{BIO}_{12}$ & 0,6033 & $-0,3940$ & 0,3797 \\
\hline $\mathrm{BIO}_{13}$ & 0,1314 & $-0,0321$ & 0,0712 \\
\hline $\mathrm{BIO}_{14}$ & 0,0109 & $-0,0083$ & $-0,0007$ \\
\hline BIO15 & 0,0017 & 0,0017 & 0,0049 \\
\hline BIOı6 & 0,3216 & $-0,2094$ & 0,2591 \\
\hline BIO17 $_{17}$ & 0,0353 & $-0,0280$ & 0,0048 \\
\hline $\mathrm{BIO}_{1} 8$ & 0,2111 & $-0,0327$ & $-0,0061$ \\
\hline BIO19 & 0,0338 & $-0,0424$ & 0,0244 \\
\hline CTI & 0,0604 & $-0,2362$ & $-0,1667$ \\
\hline SLOPE & 0,1952 & 0,6782 & $0,575^{1}$ \\
\hline ELEVATION & $-0,5550$ & $-0,0419$ & 0,5266 \\
\hline VARIANCE & $42 \%$ & $31 \%$ & $14 \%$ \\
\hline
\end{tabular}




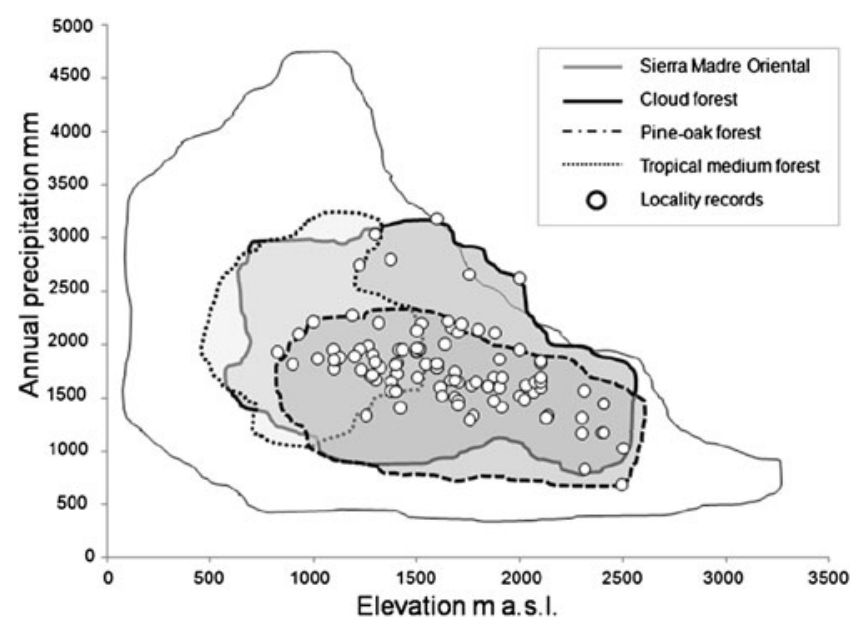

Figure 5. Comparison of the two main variables values (annual precipitation and altitude) in the potential distribution of the Bearded Wood Partridge defined by vegetation types (remarked by diferent lines), the locality records (white dots) and the Sierra Madre Oriental (thin solid line).

records for the species. Considering the importance of the species (because of its risk category) and its known range extension, the total of $4 \mathrm{I}$ historical records is low, especially considering that the avifauna in the SMO region is relatively well known (Navarro-Sigüenza et al. 2004). This may result from the evasive behaviour that is characteristic of the species.

The collection of 95 new records in just half a year of field work, with an average of four days of monitoring per month was very high in comparison with the number of historical records; this was perhaps the result of the new methods used, both in the selection of potential areas to search (from the first modelling exercise), and more intensive search effort using the auditory playback method. However, this greater success also suggests that the species is more common than was previously thought, on the basis of observations.

On the other hand, due to the fact that the field trips were not exclusively restricted to sites predicted by the first modelling exercise, there were some localities where the species was not predicted by the first modelling exercise (e.g. Villa and Nauzontla, in Puebla; Atzalán and Tepetlán, in Veracruz; and Santa María Chilchotla, in Oaxaca; Appendix 1). However, these localities did correspond to areas close to those predicted by the first modelling exercise (i.e. at an average distance of less than $3 \mathrm{~km}$ ), so in general the first model allowed for the optimisation of sampling effort in the field. This also helped us validate the presence of the species in localities with very old records, for example Miramar in Xilitla, SLP, where it was recorded in 1950 (Davis 1952) or in Huachinango, Puebla, in 1947 (Collar et al. 1992).

The final modelling exercise (based on 136 localities) for both algorithms (GARP and MaxEnt), produced maps whose predictions of geographical potential suggested the presence of Bearded Wood Partridge in areas located in the middle of the historic localities, thereby giving geographical continuity to the locality records throughout the known distribution area. Based on the extent, location, and shape of the predicted area, which also included a high percentage of locality records used to validate the models (more than $95 \%$ ), we believe that the predictions made by GARP and MaxEnt are both reliable representations of the actual distribution of the species. The first tended to over-predict and the second tended to over-fit with respect to the localities used; however, the areas predicted by both algorithms are similar in shape and extent.

Aguilar (2000) suggested that the species was present in the SNO and even further south, based on the continuous of vegetation and well preserved cloud forest. However, since we did not detect 
it during our intensive search in the Sierra Norte of Oaxaca, we suggest that the Bearded Wood Partridge is absent from this region even though it offers pristine cloud forest and environmental conditions favourable for the species. While the possibility of local extinction cannot be ruled out, there is no historical evidence of this species's presence in the SNO (Binford 1988). Furthermore, although Aguilar (2000) recorded the species in Puerto Soledad, Oaxaca (the southernmost known locality record), in our study the presence of the species was only verified for Chilchotla, a town near Puerto de la Soledad, Oaxaca. No localities were recorded further south (Figure 1). An absence of records of a species is dependent on several factors, including the methods employed in searching for it, the season of the year, the climatic conditions and does not on its own indicate true biological absence. Although our results suggest that the species is absent from this region, they are not conclusive and future surveys are needed to confirm this.

Based on information gathered in the field and an analysis of the geography of the region, we suggest that the Santo Domingo River in Oaxaca, located approximately $10 \mathrm{~km}$ south of the towns of Puerto Soledad and Chilchotla, represents the southernmost limit of Bearded Wood Partridge's distribution, and is a geographical and environmental barrier to the species (accessibility sensu Soberón and Peterson 2005 and Soberón 2007). We make this assertion because the river has an average altitude of $200 \mathrm{~m}$ in the $\mathrm{SNO}$, and is characterised by a warm climate with evergreen and semi-deciduous forests and, coincidentally, it is known that this river represents a distribution limit for other species (e.g. mammals such as Jalapan pine vole Microtus quasiater and Big small-eared shrew Cryptotis magna; and amphibians such as Pseudoeurycea bellii; Paniagua and Morrone 2009).

With regard to the limits of the distribution to the east, west and north, it is most likely environmental conditions that shape the geographical pattern observed, since according to the ENM these environmental requirements are not met beyond the known recorded locations, unlike the southern region of the SNO. The species's geographical distribution is represented by the environmental conditions found over $17,956 \mathrm{~km}^{2}$ according to GARP and $12,974 \mathrm{~km}^{2}$ based on MaxEnt. In spite of the differences between the two algorithms, in both cases, the shape and location of the distribution area, as well its approximate extent, are twice the 6,900 $\mathrm{km}^{2}$ listed by IUCN (2000) and still used today. This indicates that there are historical localities of the species that apparently were not considered by IUCN (2000): south-east of Hidalgo, north of Puebla and northern Oaxaca around its border with Puebla (Figure 1). During our field surveys we identified the species at $91 \%$ of the places we visited, and on average we obtained 4.3 responses from different groups of individuals per locality. Although the abundance data are not presented per locality, the response data are of great value considering both the evasive behaviour of the species and the values previously reported by Eitniear et al. (2001).

In relation to the environmental description, we know that the SMO is a continuous geographical feature with a broad range of environmental conditions (two of which are represented in Figure 4: annual precipitation and elevation), and where the restriction of the potential distribution of the species is observed. In addition, considering the environmental conditions provided by the various types of vegetation (Figure 4), the ranges of altitude and precipitation in cloud forest had the greatest overlap with the potential distribution, unlike the tropical medium forest, which had more restricted ranges for these two variables. While pine-oak forests occurred in a favourable elevation range, the range of precipitation they receive would be restrictive for this species. The wide range of environmental conditions is reflected by the various types of vegetation in which the species is found, with the highest percentage of records in cloud forest $(65.4 \%)$, followed by pine-oak forests $(27.2 \%)$ and finally, tropical medium forest with $10(7.3 \%)$.

Analysis of the variables associated with the potential presence of the species (Figure 2) shows that Bearded Wood Partridge requires specific combinations of ranges which, identified by the analysis of PCA (Figure 3, Table 2), facilitate the recognition of its patterns of environmental distribution (Figure 4). Although the SMO is a continuous geographical feature, the species is restricted geographically and ecologically to certain ranges of annual precipitation and elevation. IUCN (2000) suggests the species is present across an elevational band of 900-3,100 m; however, 
in this study we did not record it above 2,500 $\mathrm{m}$, and even the prediction of the final ENM (that allows for extrapolations) did not predict it at these elevations; though it is possible that the species occurs there.

This study has expanded our knowledge of the known environmental distribution of Bearded Wood Partridge. In spite its known preference for the environmental conditions of the cloud forest, we also found it in other types of vegetation such as pine-oak forest and tropical medium forest, showing that the species is not restricted to the cloud forest as was previously thought (Leopold 1977, Collar et al. 1992, Howell and Webb 1995). On the other hand, during the field trips, the majority of the localities where we recorded the species were in landscapes with partially (and sometimes highly) disturbed forests, confirming that the species is tolerant of different degrees of habitat alteration and disturbance, as suggested earlier (Eitniear et al. 2001, Aguilar 2003), although the degree of tolerance is not known. Considering this, in combination with its geographical distribution, ecological requirements and abundance, we would suggest that the species not be regarded as "Endangered" as it is currently listed according to Mexican Legislation (SEMARNAT 2011). We would also suggest that while the species is well placed in the "Vulnerable" category as defined by IUCN (2000), its geographical range should be redefined. Finally, we hope that the results of this study will stimulate further research on the natural history, abundance and distribution of Bearded Wood Partridge at finer scales, in order to contribute to the long-term survival of this enigmatic partridge.

\section{Acknowledgements}

Adriana Sandoval, Antonio Maruri, Claudia Gallardo and Pedro Mota helped with the field work. Adolfo Navarro and Sergio Aguilar contributed historical locality records. Rosario Landgrave provided assistance with the GIS. Antonio Guillén and Eduardo Pineda provided logistical support during the field work. This study benefited from the support of the Centro Tlaxcala de Biología de la Conducta de la Universidad Autónoma de Tlaxcala and the Instituto de Ecología, A. C. The Consejo Nacional de Ciencia y Tecnología (CONACYT) and the Programa de Movilidad Estudiantil (ECOES) provided the first author with financial support in the form of a scholarship and a field work grant, respectively.

\section{References}

Aguilar, S. (2000) Registro de la Perdiz veracruzana o Chivizcoyo (Dendrortyx barbatus Gould) en la Sierra Norte de Oaxaca. Huitzil 1: 9-11.

Aguilar, S. (2003) Perdiz veracruzana o Chivizcoyo (Dendrortyx barbatus). Pp. 167-168 in H. Gómez de Silva and A. Oliveras de Ita, eds. Conservación de aves: experiencias en México. México, DF: CIPAMEX, National Fish and Wildlife Foundation, CONABIO.

Aldama, A., Goettsch, B., Soberón, J., Tambutti, M., Sánchez, O. and Medellín, R. (2007) Método de evaluación del riesgo de extinción de las especies silvestres en México (MER). México DF, México: Instituto Nacional de Ecología.

Anderson, R. P., Gómez-Laverde, M. and Peterson, A. T. (2002) Geographical distri- butions of spiny pocket mice in South America: insights from predictive models. Global Ecol. Biogeog. 11: 131-141.

Anderson, R. P., Lew, D. and Peterson, A. T. (2003) Evaluating predictive models of species' distributions: criteria for selecting optimal models. Ecol. Model. 162: 211-232.

Binford, L. C. (1988) A distributional survey of the birds of the Mexican state of Oaxaca. Ornithol. Monogr. 43: 1-418.

Carroll, J. and Hoogesteijn, A. (1995) Observations of the Venezuelan Wood Quail at Rancho Grande, Henri Pittier National Park Venezuela Pp. 67-72in D. Jenkins, ed. Annual Review WPA 1993/1994. Reading, UK: World Pheasant Association.

Carroll, C., Zielinski, W. J. and Noss, R. F. (1999) Using presence-absence data to 
build and test spatial habitat models for the fisher in the Klamath Region, USA. Conserv. Biol. 13: 1344-1359.

Collar, N. J., Gonzoga, L. P., Krabbe, N., Madroño, N., Naranjo, L. G., Parker, T. A. and Wege, D. C., eds (1992) Threatened birds of the Americas. Cambridge, UK: International Council for Bird Preservation.

Cowley, M. J. R., Wilson, R. J., León-Cortés, J. L., Gutierrez, D. C., Bulman, R. and Thomas, C. D. (2000) Habitat-based statistical models for predicting the spatial distribution of butterflies and day-flying moths in a fragmented landscape. J. Appl. Ecol. 37: $60-72$.

Davis, I. L. (1952) Winter bird census at Xilitla, San Luis Potosi. Condor 54: 345-350.

Eitniear, J. C., Aguilar, S., Gonzáles, V., Pedraza, R. and. Baccus, J. T. (200o) New records of Bearded Wood Partridge, Dendrortyx barbatus (Aves: Phasianidae) in México. Southwestern Nat. 45: 238-241.

Eitniear, J. C., Aguilar, S., Baccus, J. T. and Carroll, J. P. (2001) Response rates of Bearded Wood-Partridges (Dendrortyx barbatus, Aves: Phasianidae) to playback of a recorded call. Vida Silvestre Neotrop. 10: 1-2.

Eitniear, J. C., Aguilar, S. and Cornejo, J. (2008) Observing the bearded wood partridge: a rare and elusive species. Neotrop. Birding 1: 67-71.

Elith, J. H., Graham, C. P., Anderson, R., Dudik, M., Ferrier, S., Guisan, A. J., Hijmans, R., Huettmann, F. R., Leathwick, J., Lehmann, A., Li, J. G., Lohmann, L. A., Loiselle, B., Manion, G., Moritz, C., Nakamura, M., Nakazawa, Y., McC Overton, J., Peterson, A. T., Phillips, S., Richardson, K., Scachetti-Pereira, R., Schapire, R., Soberon, J., Williams, S. S., Wisz, M. and Zimmermann, N. 2006. Novel methods improve prediction of species' distributions from occurrence data. Ecography 29: 129-151.

ESRI (1999) ArcView GIS, V. 3.2. California, USA: Environmental Systems Research Institute Inc.

GBIF (Global Biodiversity Information Facility) (2010) http://www.gbif.org (accessed January 2010).

Godown, M. E. and Peterson, A. T. (2000) Preliminary distributional analysis of US endangered bird species. Biodivers. Conserv. 9: 1313-1322.

Google Earth (2010) http://earth.google.es (accessed January-August 2010).

Hijmans, R. J. Cameron, S. E., Parra, J. L., Jones, P. G. and Jarvis, A. (2005). Very high resolution interpolated climate surfaces for global land areas. Internatn. J. Climatol. 25: 1965-1978.

Howell, S. and Webb, S. (1995). A Guide to the birds of Mexico and northern Central America. New York, USA: Oxford University Press.

INEGI (1992) Cartas topográficas 1:500oo. Aguascalientes, México: Instituto Nacional de Estadística, Geografia e Informática.

INEGI (2003) http://www.inegi.gob.mx (accessed December 2010).

IUCN (2008) IUCN Red List of Threatened species. http://www.iucnredlist.org (accessed January 2010).

Leopold, A. (1977) Fauna silvestre de México. México, DF: Ediciones del Instituto Mexicano de Recursos Naturales.

Lowery, H. J. and Newman, J. R. (1951). Notes on the ornithology of southern San Luis Potosí. Wilson Bull. 63: 315-322.

Manel, S., Dias, J. M. S., Buckton, T. and Omerod, S. J. (1999) Alternative methods for predicting species distribution: an illustration with Himalayan river birds. J. Appl. Ecol. 36: 734-747.

Martínez-Morales, M. (2007) Avifauna del bosque mesófilo de montaña del noreste de Hidalgo, México. Rev. Mexicana de Biodiversidad 78: 149-162.

Mota-Vargas, C. (2008) Distribución, abundancia relativa y uso de hábitat del chivizcoyo Dendrortyx barbatus (Aves: Odontophoridae) en el municipio de Coatepec, Ver. B.Sc. Thesis. Veracruz, México: Universidad Veracruzana.

Mota-Vargas, C. and Rojas-Soto, O. R. (2012) The importance of defining the geographic distribution of species for conservation: The case of the Bearded Wood-Partridge. J. Nature Conserv. 20: 10-17.

Navarro-Sigüenza, A., Peterson, A. T. and Gordillo-Martínez, A. (2003) Museums working together: the atlas of the birds of Mexico. Bull. Brit. Ornithol. Club Suppl. 123A: 207-225. 
Navarro-Sigüenza, A., Garza-Torres, H. A., López de Aquino, S., Rojas-Soto, O. and Sánchez-González., L. A. (2004) Patrones biogeográficos de la avifauna de la Sierra Madre Oriental, México. Pp. 439-467 in I. Luna-Vega, J. J. Morrone, and D. Espinoza eds. La Sierra Madre Oriental: un enfoque multidisciplinario. México, DF: Facultad de Ciencias UNAM.

Paniagua, L. L. and Morrone, J. J. (2009) Do the Oaxacan Highlands represent a natural biotic unit? A cladistic biogeographical test based on vertebrate taxa. J. Biogeog. 36: 1939-1944.

Pearson, R. G., Raxworthy, C., Nakamura, M. and Peterson, A. T. (2006) Predicting spe-

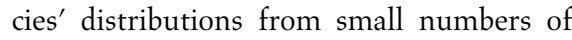
occurrence records: A test case using cryptic geckos in Madagascar. J. Biogeog. 34: 102117.

Peterson, A. T. (2001) Predicting species geographic distributions based on ecological niche modeling. Condor 103: 599-605.

Peterson, A. T. (2003a) Predicting the geography of species' invasions via ecological niche modeling. Q. Rev. Biol. 78: 419-433.

Peterson, A. T. (2003 b) Projected climate change effects on Rocky Mountain and Great Plains birds: generalities of biodiversity consequences. Global Change Biol. 9: 647-655.

Peterson, A. T., Navarro, S. A. and BenítezDíaz, H. (1998) The need for continued scientific collecting; a geographic analysis of Mexican bird specimens. Ibis 140: 288-294.

Peterson, A. T., Martínez-Campos, C., Nakazawa, Y. and Martinez-Meyer, E. (2005) Time-specific ecological niche modeling predicts spatial dynamics of vector insects and human dengue cases. Trans. $R$. Soc. Trop. Med. Hygiene 99: 647-655.

Phillips, S. J., Anderson, R. P. and Schapire, R. E. (2006) Maximum entropy modeling of species geographic distributions. Ecol. Model. 190: 231-259.

Phillips, S. J., Dudík, M. and Schapire, R. E. (2004) A maximum entropy approach to species distribution modeling. Proceedings of the 21st International Conference on Machine Learning; Banff, Canada.

Pulliam, H. R. and Dunning, J. B. (1997) Demographic processes: population dynamics on heterogeneous landscapes. Pp. 203-232 in G. K. Meffe and C. R. Carroll, eds. Principles of conservation biology. 2nd Edition. Sunderland, MA: Sinauer Associates, Inc.

Raxworthy, C. J., Martínez-Meyer, E., Horning, N., Nussbaum, R. A., Schneider, G. E., Ortega-Huerta, M. A. and Peterson, A. T. (2003) Predicting distributions of known and unknown reptile species in Madagascar. Nature 426: 837-841.

REMIB (Red Mundial de Información sobre Biodiversidad) (2010) http://www.conabio. gob.mx (accessed January 2010).

Rojas-Soto, O., Según-Sanchez, F. J. and Navarro-Sigüenza, A. (2001) Additional information on the avifauna of Queretaro, México. Cotinga 15: 48-52.

Rojas-Soto, O., Alcántara-Ayala, O. and Navarro-Sigüenza, A. (2003) Regionalization of the avifauna of the Baja California peninsula, Mexico: a parsimony analysis of endemicity and distributional modeling approach. J. Biogeog. 30: 449-461.

Rojas-Soto, O., Martínez-Meyer, E., Navarro, S. A., Oliveras de Ita, A., Gómez de Silva, H. and Townsend Peterson, A. (2008) Modeling distributions of disjunct populations of the Sierra Madre Sparrow. J. Field Ornithol. 79: 245-253.

SEMARNAT (Secretaría de Medio Ambiente y Recursos Naturales). (2011) Diario Oficial de la Federación (2001, 2011) Norma Oficial Mexicana NOM-059- ECOL-2001, Protección ambiental-Especies nativas de México de flora y fauna silvestres-Categorías de riesgo y especificaciones para su inclusión, exclusión o cambio-Lista de especies en riesgo. México: Secretaría de Gobernación.

Soberón, J. (2007) Grinnellian and Eltonian niches and geographic distributions of species Ecol. Lett. 10: 1115-1123.

Soberón, J. and Peterson, A. T. (2005). Interpretation of models of fundamental ecological niches and species distributional areas. Biodivers. Informatics 2: 1-10.

Stockwell, D. R. B. and Noble, I. R. (1991) Induction of sets of rules from animal distribution data: a robust and informative method of data analysis. Math. Comp. Simulat. 32: $249-254$.

Stockwell, D. R. B. and Peters, D. (1999) The GARP modelling system: problems and 
solutions to automated spatial prediction. Geog. Inf. Sci. 13: 143-158.

Tsoar, A., Allouche, O., Steinitz, O., Rotem, D. and Kadmon, R. (2007) A comparative evaluation of presence-only methods for modeling species distribution. Divers. Distrib. 13: 397-405.

USGS (United States Geological Survey). (2001) HYDRO IK http://edc.usgs.gov (accessed January- August 2010)
Villa-Bonilla, B., Rojas-Soto, O., ColodnerChamudis, G. and Tejeda-Cruz, C. (2008) Inventarios municipales de avifauna y su aplicación a la conservación el caso de Zacapoaxtla, Puebla, México. Ornitol. Neotrop. 19: 531-551.

Warren, D. L., Glor, R. E. and Turelli, M. (2008) Environmental niche equivalency versus conservatism: quantitative approaches to niche evolution. Evolution 62: 2868-2883.

\section{CLAUDIO MOTA-VARGAS}

Maestría en Ciencias Biológicas, Universidad Autónoma de Tlaxcala. Carretera Tlaxcala-Puebla km 1.5 colonia Xicohtencatl, Tlaxcala, Tlaxcala 9007o, México.

OCTAVIO R. ROJAS-SOTO*

Red de Biología Evolutiva, Instituto de Ecología, A. C., Km. 2.5 carretera antigua a Coatepec 351, Congregación El Haya, Xalapa, Veracruz 91070, México.

\section{CARLOS LARA}

Centro Tlaxcala de Biología de la Conducta, Universidad Autónoma de Tlaxcala., Carretera Tlaxcala-Puebla km 1.5 colonia Xicohtencatl, Tlaxcala, Tlaxcala 9oo7o, México.

\section{CITLALLI CASTILLO-GUEVARA}

Centro de Investigación en Ciencias Biológicas, Universidad Autónoma de Tlaxcala, Km 10.5 Autopista Tlaxcala-San Martín Texmelucan San Felipe Ixtacuixtla, Tlaxcala 90120, México.

\section{CLAUDIA BALLESTEROS-BARRERA}

Departamento de Biología, Universidad Autónoma Metropolitana Iztapalapa, A.P 55-35, Av. San Rafael Atlixco \#186 Col. Vicentina, Del. Iztapalapa C.P. o934o, México, D.F.

*Author for correspondence; email: octavio.rojas@inecol.edu.mx

Received 27 October 2011; revision accepted 11 April 2012; Published online 12 July 2012 
Appendix 1. Localities visited during the field work showing the presence and absence of Dendrortyx barbatus. The first column lists the Mexican states (SLP = San Luis Potosí, Hgo = Hidalgo, Ver = Veracruz, Pue = Puebla, Oax = Oaxaca). The second column lists the Municipality, and the third and fourth columns are the consecutive numbers of the localities visited and their names. The last two columns give the number of records by locality as well the date recorded.

\begin{tabular}{|c|c|c|c|c|c|}
\hline State & Municipality & \multicolumn{2}{|c|}{ Locality } & Records & Date \\
\hline \multicolumn{6}{|c|}{ Presence } \\
\hline \multirow[t]{3}{*}{ SLP } & Xilitla & 1 & Miramar Viejo & 8 & 8 April \\
\hline & & 2 & La Trinidad & 7 & 9 April \\
\hline & & 3 & La Silleta & 1 & 1o April \\
\hline Hgo & Chapulhuacán & 4 & El Sótano & 7 & 16 April \\
\hline \multirow[t]{12}{*}{ Ver } & Zilacatipán & 5 & Zilacatipán & 4 & 21 April \\
\hline & Alpatlahuac & 6 & Alpatlahuac & 5 & 4 July \\
\hline & Huatusco & 7 & Las Cañadas & 2 & 6 July \\
\hline & Ixhuacán de los Reyes & 8 & Buena Vista & 4 & 29 July \\
\hline & Cosautlán & 9 & El Mirador & 2 & 30 July \\
\hline & Coscomatepec & 10 & Huatusco-Coscomatepec & 3 & 4 August \\
\hline & Tlacolulan & 11 & Tlacolulan & 4 & 24 August \\
\hline & Coatepec & 11 & El Pino & 1 & 28 August \\
\hline & Ixtaczoquitlán & 12 & Cerro Chicahuaxtla & 1 & 7 September \\
\hline & Atzalán & 13 & Atzalán & 2 & 19 September \\
\hline & Acatlán & 14 & Acatlán & 7 & 22 September \\
\hline & Tepetlán & 15 & Tepetlán & 7 & 23 September \\
\hline \multirow[t]{5}{*}{ Pue } & Ahuacatlán & 16 & Ahuacatlán & 6 & 26 October \\
\hline & Nauzontla & 17 & La Unión & 3 & 27 October \\
\hline & Tetela de Ocampo & 18 & La Sierra & 1 & 27 October \\
\hline & Huachinango & 19 & Huachinango & 2 & 27 October \\
\hline & Xicotepec & 20 & Xicotepec & 1 & 28 October \\
\hline Hgo & Tenango de Doria & 21 & Tenango de Doria & 12 & 28 October \\
\hline \multirow[t]{2}{*}{ Oax } & Santa Maria Chilchotla & 22 & Chilchotla & 5 & 23 November \\
\hline & & & Total & 95 & \\
\hline \multicolumn{6}{|c|}{ Absence } \\
\hline \multirow[t]{3}{*}{ Oax } & $\begin{array}{l}\text { Concepción Pálpalo - Santa } \\
\text { María Tlalixtac }\end{array}$ & & Concepción Pápalo & 8 & 22 November \\
\hline & Valle Nacional-La Esperanza & & La Esperanza & 12 & 23 November \\
\hline & & & Total & 20 & \\
\hline
\end{tabular}

